Gut, 1978, 19, 798-801

\title{
Parietal cell hyperplasia induced by long-term administration of antacids to rats
}

\author{
G. MAZZACCA ${ }^{1}$, F. CASCIONE, G. BUdillon, L. D'AgOSTINO, L. Cimino, \\ AND C. FEMIANO \\ From the Division of Gastroenterology, 2nd School of Medicine, University of Naples, and the \\ Department of Pathology, Institute for Tumoral Diseases, Naples, Italy
}

SUMMARY Suspension of magnesium and aluminum hydroxide $(30-60 \mathrm{mEq} / 24 \mathrm{~h})$ or a comparable volume of water was orally administered by gastric intubation to two groups of 20 male wistar rats each over 60 days. The antacid treatment led to a significant increase in the height $(0.464 \pm 0.02 \mathrm{~mm}$ v. $0.318 \pm 0.06)$ and in the volume $\left(472 \pm 32 \mathrm{~mm}^{3} \mathrm{v} .328 \pm 45\right)$ of the fundic mucosa of the stomach, in the average count of parietal cells per unit area of the mucosa $(32 \cdot 37 \pm 1 \cdot 8 \mathrm{v} .22 \cdot 3 \pm 1 \cdot 6)$, and in the total parietal cell population of the stomach $\left(53.6 \pm 3.5 \times 10^{6} \mathrm{v} .43 .2 \pm 3.7 \times 10^{6}\right)$. Furthermore fasting serum gastrin concentration was significantly higher in the antacid treated rats $(81 \cdot 2 \pm 7 \cdot 4$ $\mathrm{pg} / \mathrm{ml})$ than in control animals $(56.9 \pm 6.9 \mathrm{pg} / \mathrm{ml})$.

It is known that a feedback mechanism governs the relationship between antral gastrin release and intraluminal gastric $\mathrm{pH}$ (Walsh et al., 1975). Furthermore, gastrin exerts a trophic influence on the gastric mucosa with increase in the parietal cell mass (Crean et al., 1969). Therefore it is tempting to speculate that long-term antacid administration may cause parietal cell hyperplasia by increasing fasting serum gastrin concentrations.

The present investigation was indertaken to examine this hypothesis. Serum gastrin levels and parietal cell mass were determined in rats submitted to prolonged periods of intensive antacidadministration.

\section{Methods}

Forty male rats of Wistar strain aged about 6 weeks and weighing between $100 \mathrm{~g}$ were used. All the animals were allowed to feed ad libitum on the same diet of standard rat cake. The animals were divided in two groups each of 20 rats. One group (A) received antacids, the other (B) was the control. A suspension of magnesium and aluminum hydroxide (Maalox) was used as antacid. An amount of the antacid capable of neutralising $2 \mathrm{mEq} \mathrm{HCl}$ was instilled by intubation into the stomach seven to eight times daily in each rat from 8 a.m. to 8 p.m.

\footnotetext{
${ }^{1}$ Address for reprints: G. Mazzacca, Divisione di Gastroenterologia, Nuovo Policlinico, 80131 Napoli, Italy.

Received for publication 11 April 1978
}

The animals of group B received each time and by the same procedure a comparable volume of water. During the night each animal was housed in a separate cage and the antacid suspension was the only drinking fluid available to the rats of group A. $12.2 \pm 6.4 \mathrm{ml} / 12 \mathrm{~h}$ of antacid (corresponding to $31.47 \pm 16.51 \mathrm{mEq})$ and $19.3 \pm 3.9 \mathrm{ml} / 12 \mathrm{~h}$ of water were the mean amounts of drinking fluid consumed during the nights by each rat of group $\mathbf{A}$ and group B respectively.

During the experiment nine rats of group $A$ and seven of group B died and were discarded. The mortality was caused mostly by tracheal aspiration and was observed in both groups mostly during the first few days of the experiment and later dropped off, probably because, as the animals grew up, intubation was easier. The survivors remained well. They all gained weight at a rate which was just below the average for intact animals of the same colony. The rats were killed by chloroform on the 60th day from the start of the treatment schedule. Blood was withdrawn directly from the heart for serum gastrin determinations. Serum was stored in the deep-freeze $\left(-25^{\circ} \mathrm{C}\right)$ until analysis. The concentration of gastrin in serum was determined by radioimmunoassay for human gastrin as previously described (Mazzacca et al., 1974).

HISTOLOGICAL EXAMINATIONS

The stomach was removed as quickly as possible after death and was opened along the greater 
curvature, washed, and pinned flat with the serosal surface downward in such a way as to eliminate mucosal folds and fixed in the flattened position by immersion in formol-saline. After fixation the flattened specimens were removed and trimmed carefully to separate the fundus from the antrum (in the rat the fundus and antrum of the stomach are readily distinguished from one another by the naked eye). The fundic area was then traced carefully on white paper and the area was determined by four consecutive readings with a planimeter. The measurements were reproducible within the limits of error of the order of $5 \%$. Six full thickness strips of the gastric wall were removed from each fundus parallel to the axis of the curvatures. Longitudinal sections ware cut at $3 \mu$ from each strip at right angles to the surface of the mucosa. The sections were stained by the method of Marks and Drysdale (1957) as modified by Naik et al. (1971). The various gastric mucosal secretory cells are well differentiated with this technique, the mucous cells take up red stain; peptic cells blue; and parietal cells yellow. Cell counts were done using a calibrated ocular grid (magnification $\times$ 900). Counts were made of all parietal cell nuclei or nuclear fragments seen in a column of tissue $0.1 \mathrm{~mm}$ broad and extending from the base to the surface of the mucosa. Five counts from randomly selected fields were made on each section and an 'average count per unit area' was calculated for each stomach by dividing the number of cells seen by the number of counts made. Mucosal height from surface to muscularis mucosa was measured at intervals of $4 \mathrm{~mm}$ along the length of each section using the calibrated eyepiece and an average mucosal height was calculated for each stomach. The 'average cell count per unit area' was corrected for tissue shrinkage from dehydration and the embedding process (Card and Marks, 1960).

Furthermore, to compensate for the inclusion of nuclear fragments, a correction factor for nuclear over-estimation was calculated (Abercrombie, 1946). after estimating the actual thickness of the mucosal section (Morengo, 1944) and the mean nuclear length. The corrected count per unit area was thus obtained by multiplying the observed count $x$ shrinkage factor $\times$ correction factor for nuclear over-estimation. The average corrected count per unit area was then referred to the total surface area of the fundus to give an estimate of the total parietal cell population of the stomach. The volume of the fundic mucosa was calculated as the product of the surface area by the mean height of the mucosa.

ERRORS AND STATISTICAL ANALYSIS

The source of error in the cell counts due to subjective bias was eliminated by coding each rat according to a set of random numbers known only to one of us, so that all of the steps involved from removing stomach to the actual calculation of the results were carried out in ignorance of the identity of the stomach under consideration. Sampling errors are another source of error which might influence the results obtained in the investigation. Distribution of parietal cells could be variable; if so, the sample strips might not be truly representative of the entire fundic mucosa. To test this, actual variation in the 'average count per unit area' in the data taken from all the rats of the experiment representing 22 stomachs or 132 individual strips was examined by the method of analysis of variance. The results (Table 1, S) show that there was no significant variation in the values obtained between the six sites sampled in individual stomachs. The reliability of the sampling procedure was further supported by the absence of any significant variability of the effects of treatments on average 'count' per unit area among the six sites sampled in individual stomachs (Table 1, TS).

Table 1 Statistical evaluation by analysis of variance of average corrected numbers of parietal cells per unit area from 22 rats in study

\begin{tabular}{|c|c|c|c|c|}
\hline \multirow[t]{2}{*}{ Variation } & \multicolumn{4}{|c|}{ Analysis of variance } \\
\hline & $\begin{array}{l}\text { Degree of } \\
\text { freedom }\end{array}$ & $\begin{array}{l}\text { Sum of } \\
\text { squares }\end{array}$ & Variance & $\begin{array}{l}\text { Value for } \\
P\end{array}$ \\
\hline Strips (S)* & 5 & $56 \cdot 31$ & $11 \cdot 26$ & NS \\
\hline Treatment $(\mathrm{T}) \dagger$ & 1 & $3120 \cdot 94$ & 3120.94 & $<0.001$ \\
\hline $\begin{array}{l}\text { Interaction } \\
\quad \text { strip-treatment (TS) } \ddagger\end{array}$ & 5 & $92 \cdot 18$ & $18 \cdot 44$ & NS \\
\hline Error & 120 & $1712 \cdot 65$ & $14 \cdot 27$ & \\
\hline Total & 131 & $5002 \cdot 08$ & & \\
\hline
\end{tabular}

*Variation in average 'count' per unit area among six sample strips from 22 stomachs representing the two rat groups of the investigation. +Comparison of average 'count' per unit area between antacidtreated group and controlled group.

$\ddagger$ Variation of the effects of treatment on average 'count' per unit area among six sample strips from 22 stomachs representing the two rat groups of the investigation.

For comparing average corrected numbers of parietal cells per unit area between the control group and the antacid-treated group the method of analysis of variance was also used. Statistical analysis of the other parameters (surface area, height, and volume of fundic mucosa; total parietal cell population; serum gastrin) was performed using Student's $t$-test. The significance level was fixed by $P<0.05$.

\section{Results}

As shown in Tables 1 (A) and 2 the average number of parietal cells per unit area, the total parietal cell population, the height, and the volume of the fundic 
mucosa were significantly increased in the antacid treated group of rats compared with the controls. The fundic surfaces were not significantly different in the two groups of rats. Therefore the increase in the total parietal cell population observed in group $\mathbf{A}$ could be due only to an increase in the number of parietal cells per unit area. This means that there was an increase in the number of parietal cells in gastric glands; this effect, in turn, implies an increase in the height of the glands and it probably explains the increase in the height of the fundic mucosa.

Table 3 shows that the mean fasting serum gastrin concentration was significantly higher in group A in comparison with the value observed in the control group.

Table 2 Effect of long-term antacid administration on gastric mucosa in rat

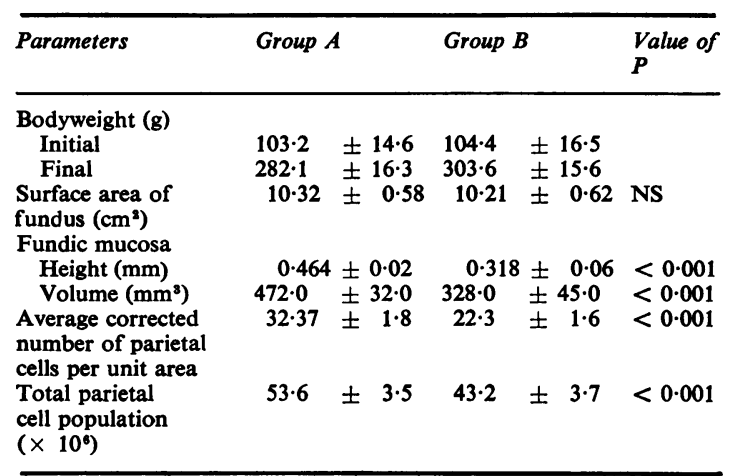

Group A: antacid treated rats.

Group B: controls.

Table 3 Fasting serum gastrin concentrations in antacid-treated rats (group A) and in controls (group B)

\begin{tabular}{lll}
\hline Group of rats & $\begin{array}{l}\text { Serum gastrin }(p g / m l) \\
(\text { mean } \pm S D)\end{array}$ & $P$ \\
\hline A & $81.2 \pm 7.4$ & $<0.001^{*}$ \\
\hline
\end{tabular}

*Compared with group B.

\section{Discussion}

Our study shows that prolonged and intensive administration of antacids led both to an increase of fasting serum gastrin conceutration and to an increase in the total parietal cell population of the stomach. The increase in the total parietal cell population appeared to be due to an increased number of parietal cells in the gastric glands.

Gastrin exerts trophic influence on parietal cells (Walsh et al., 1975) and prolonged injection of pentagastrin has been shown to cause parietal cell hyperplasia in rats (Crean et ul., 1969; Isenberg et al., 1973). Therefore it is likely that, in our antacid treated rats, the increase in the total parietal cell population was causally related to the increase of serum gastrin concentration. However, in this regard it should be stressed that secretion of gastrin has been shown to occur in some animal species with a circadian rhythm (Wiesenfeld et al., 1977). Whether in our rats antacid administration abolished gastrin biorhythm is unknown. Furthermore, some data in the literature suggest the presence in the rat of a unique mammalian gastrin which is larger than heptadecapeptide and with a longer half-life (Holmquist et al., 1977).

We did not evaluate gastric acid secretion in our rats. Therefore the possibility that, in rats of group A gastric acid output did not rise in parallel to the increase in total parietal cell population cannot be ruled out. It is of interest that Hall (1976) recently suggested that the additional parietal cells produced by the trophic action of hypergastrinaemia are ineffective.

In conclusion, in our experimental model longterm intensive antacid administration caused parietal cell hyperplasia. Whether intensive therapy with antacids may have a similar effect in man remains speculative.

\section{Addendum}

Since submitting this paper for publication, Witzel et al. (1977) have published a paper showing that in rat prolonged metiamide administration leads to an increase in the parietal cell mass, probably via hypergastrinaemia.

The authors wish to thank Professor A. Mango, professor of statistics at the University of Naples, for his contribution to the statistical evaluation.

\section{References}

Abercrombie, M. (1946). Estimation of nuclear population from microtome sections. Anatomical Record, 94, 239-247.

Card, W. I., and Marks, I. N. (1960). The relationship between acid output of the stomach following 'maximal' histamine stimulation and parietal cell mass. Clinical Science, 19, 147-163.

Crean, G. P., Marshall, M. W., and Rumsey, R. D. E. (1969). Parietal cell hyperplasia induced by the administration of pentagastrin (ICI 50, 123) to rats. Gastroenterology, 57, 147-155.

Hall, W. H. (1976). Parietal cell mass and the trophic action of gastrin. Gastroenterology, 70, 823-824.

Holmquist, A. L., Walsh, J. H., and Feldman, E. J. (1977). Immunochemical distinction between rat gastrin and other mammalian gastrins. Gastroenterology, 72, 1071 (Abstract).

Isenberg, J. I., Walsh, J. H., and Grossman, M. I. (1973). Zollinger-Ellison syndrome. Gastroenterology, 5, 140-156. 
Marks, I. N., and Drysdale, K. M. (1957). A modification of Zimmerman's method for differential staining of gastric mucosa. Staining Technology, 32, 48.

Mazzacca, G., Budillon, G., De Marco, F., and De Ritis, F. (1974). Serum gastrin in patients with cirrhosis of the liver. Digestion, 11, 232-239.

Morengo, N. P. (1944). Paraffin secretion thickness, a direct method of measurement. Staining Technology, 19, 1-10.

Naik, S. R., Bajaj, S. C., Goyal, R. K., Gupta, D. N., and Chuttani, H. K. (1971). Parietal cell mass in healthy human stomach. Gastroenterology, 61, 682-685.
Saik, R. P., Wiesenfeld, N., Greenburg, A. G., Kripke, D. F., and Peskin, G. W. (1977). Biorhythm of gastrin. Gastroenterology. 72, 1165. (Abstract).

Walsh, J. H., Richardson, C. T., and Fordtran, J. S. (1975). pH Dependence of acid secretion and gastrin release in normal and ulcer subjects. Journal of Clinical Investigation, 55, 462-468.

Witzel, L., Halter, F., Olan, A. Y., and Häcki, W. H. (1977). Effects of prolonged metiamide medication on the fundic mucosa. A secretory and histomorphometric study in the rat. Gastroenterology, 73, 797-803. 